\title{
Leaving and staying with the employer-Changes in work, health, and work ability among older workers
}

\author{
Nina Garthe ${ }^{1}$ [D $\cdot$ Hans Martin Hasselhorn ${ }^{1}$
}

Received: 8 January 2020 / Accepted: 25 August 2020 / Published online: 6 September 2020

(c) The Author(s) 2020

\begin{abstract}
Objective The aim of this prospective study was to examine employer changes among older workers and to relate them to psychosocial work factors, health, and work ability. Four groups of employees as elaborated by Hom et al. (2012) were distinguished: Enthusiastic leavers (EL), reluctant leavers (RL), enthusiastic stayers (ES), and reluctant stayers (RS).

Methods Repeated Measures ANOVA analyses were based on data from the second and third waves $(2014,2018)$ of the German lidA Cohort Study, a representative study of employees born in 1959 or 1965.

Results The largest proportion of participants was ES (73.3\%), 13.2\% stayed with their employer although they would have preferred to leave (RS). 7.1\% changed employer between 2014 and 2018 voluntarily (EL), 6.4\% involuntarily (RL). Analyses confirmed that the four groups already differed in 2014 in terms of health, work ability, and psychosocial work factors and that these outcomes change in different characteristic patterns over time. Most outcomes improved substantially following the change among EL. RS already reported poor outcomes in 2014 and exhibited a further deterioration while staying at the undesired workplace.

Conclusion Our findings indicate that an employer change is followed by improvements of work, health, and work ability. We conclude that an inclusive labor market policy for older workers allowing for high job mobility may have the potential to contribute to considerable improvements of workers' individual working conditions, health, and work ability, thereby increasing the work participation. Also, the considerable group of RL requires increased political and scientific attention.
\end{abstract}

Keywords Employer change $\cdot$ Older workers $\cdot$ Job lock $\cdot$ Psychosocial work factors

\section{Introduction}

The demographic change in Germany leads to an aging and shrinking workforce. A consequence for many workers is the extension of their working lives. This raises the question on how older workers can manage to work until, or possibly longer than the statutory retirement age. According to the international JPI UEP working group "the positive impact of work factors that promote longer working lives and help retain workers should be given greater attention in retirement studies" (Hasselhorn and Apt 2015). One strategy proposed is the change of employer at higher working age. Such a

Nina Garthe

garthe@uni-wuppertal.de

1 Department of Occupational Health Science, School of Mechanical Engineering and Safety Engineering, University of Wuppertal, Gaußstraße 20, 42119 Wuppertal, Germany change may exhibit the potential to improve the fit between the older workers and their work, with regard to work factors, qualifications, motivation, work ability, and health, and therefore to extend the personal working life (Behrens 1998; Jahn and Ulbricht 2011; Morschhäuser 2002).

When investigating employer changes among older workers, voluntary and involuntary changes need to be differentiated. While a voluntary change is often a planned transition, losing one's job may often be unexpected, it can lead to unemployment, job search and-at best-to a new job with many uncertainties. This may constitute a substantial challenge-not least for older workers (Brauer and Clemens 2010)-and might rather bear health risks than benefits. However, comparative research on consequences of voluntary and involuntary changes is rare (Chadi and Hetschko 2014; Wagenaar et al. 2012).

But also voluntary employer changes offer not only chances but also bear risks, especially for older workers. Behrens (1998) pointed out that employer changes cannot 
be a general recommendation for all older workers who find themselves in inappropriate work situations. Beyond the risk of becoming unemployed, further obstacles keep older workers from changing, such as concerns about reduced pay after a change (Schneider 2010), the expectation of a temporary contract or a misfit of skills, and knowledge in the new job (Bailey and Hansson 1995). Morschhäuser (2006) described in her qualitative study that older workers with poor health and physically demanding work did not want to leave familiar workplaces and showed low confidence in managing a change. These psychological and further obstacles are covered by the theories on job lock and stuck at work, which point out that such a locked occupational situation may have negative impact on work and health (Huysse-Gaytandjieva et al. 2013). The aspect of involuntary staying with one's employer in contrast to voluntary staying should thus also be considered when investigating employer changes and older workers' work motivation, work ability, health, and employment perspective.

\section{Theoretical background and hypotheses}

Based on their review of employee turnover, Hom et al. (2012) presented a theory on motivational states of staying and leaving, depicting four groups of employees with different cognitive states concerning staying with or leaving the employer. The combination of two dimensions, (a) desired staying or leaving and (b) high or low perceived control of this preference, leads to four groups covering the scenarios discussed above: Enthusiastic leavers (EL), who want to and can leave, reluctant leavers (RL), who have to leave because they are forced to, reluctant stayers (RS), who stay because they feel they cannot leave although they would prefer to, and enthusiastic stayers (ES), who want to stay and feel no external pressure to leave their employer.

In all groups, work factors, especially psychosocial work factors, as well as health and work ability play a central role. EL may want to leave their employer due to a lack of person-work fit and want improvements (Mobley 1977; Trevor 2001). The work situation is perceived similarly by RS, yet they cannot leave due to diverse obstacles. Workers belonging to this group may develop work avoidance and counterproductive workplace behaviors and quit psychologically (Mobley et al. 1979; Hulin et al. 1985; Mowday et al. 1982). In contrast, RL may have to leave their employer, for example, due to low performance, and have to find a new job, which may constitute a great challenge, not least for older workers (Jackofsky 1984; Bäcker et al. 2017). Finally, ES may have a satisfying person-work fit and good work performance (Mobley 1977; Lee et al. 1999).

Previous empirical studies usually examined singular groups of the four, primarily EL (Reineholm et al. 2012), the most frequent outcomes were mental health indicators
(Liljegren and Ekberg 2008), and the most frequently investigated group are middle-aged employees (Rubenstein et al. 2018). Most studies are cross-sectional investigations using change proxies, such as job mobility intentions (Alcover and Topa 2018), instead of examining actual changes in longitudinal studies (Raeve et al. 2008).

This article aims to empirically investigate all four groups of EL, RS, RL, and ES in a longitudinal study in terms of differences and changes over time with respect to mental and physical health, work ability, and psychosocial work factors among older workers. The assumptions compiled by Hom et al. (2012) lead to two hypotheses:

H1: The groups differ significantly in terms of health, work ability, and psychosocial work factors.

$\mathrm{H} 2$ : The groups change significantly differently over time in terms of health, work ability, and psychosocial work factors.

\section{Methods}

\section{Data and sample}

The analyses are based on data from the German lidA Cohort Study on Work, Age, Health and Work participation, a representative cohort study of older employees in Germany (www.lida-studie.de). The aim of lidA is to investigate work and employment in the aging workforce. Initially employed people subject to social security contributions (no self-employed or sworn civil servants), born in either 1959 or 1965, are interviewed every three to four years in their homes (computer-assisted personal interviewing, CAPI). The data used here are derived from the second and third waves of the study, 2014 (t1) and 2018 (t2) with 4244 and 3586 participants, respectively. In 2018 the participants were 53 and 59 years old. A more detailed description of the lidA Cohort Study and its design has been given elsewhere (Hasselhorn et al. 2014; Rauch et al. 2015).

In all, 3232 workers participated in $\mathrm{t} 1$ and $\mathrm{t} 2$. In order to focus on employer changes, study participants were excluded if they were not employed full time, part time, or marginally in any of the waves. As a result, the sample consists of 2811 participants.

\section{Measures}

\section{Employer change groups}

The change of employer was assessed in the third wave in 2018 (t2) by the question: "Have you changed your employer since the last interview? (Yes/No)." Participants, who reported a change, were asked whether they changed on their 
own initiative (enthusiastic leavers), or on the initiative of their employer (reluctant leavers). Participants, who reported no change, were asked whether they would have liked to change since the last study interview in 2014 (reluctant stayers) or not (enthusiastic stayers). Thus, the four groups differentiate the participants whether they changed or not and wanted to change or not between $2014(\mathrm{t} 1)$ and $2018(\mathrm{t} 2)$.

\section{Mental and physical health}

The outcomes mental and physical health were assessed with the Short Form Health Survey (SF-12) (Nübling et al. 2006; Ware et al. 1995). Component scores ranging from 0 to 100 with a high score indicating better health were calculated. Both SF-12 scales were found to have acceptable psychometric properties and validity (Ware et al. 1996).

\section{Work ability}

To measure work ability, the second dimension of the Work Ability Index was used, which consists of three questions. Two questions refer to the actual self-assessed work ability with respect to mental and physical demands at work, respectively. The answers were weighted by the response to a third question, indicating whether the participant is mainly mentally active in the main job, mainly physically active or both equally. The resulting sum score ranges from 2 (no work ability) to 10 (high work ability). The second dimension of the Work Ability Index was shown to be a suitable short measure for work ability in occupational health research and employee surveys (Ebener and Hasselhorn 2019).

\section{Psychosocial work factors}

Psychosocial work factors were assessed with scales from the Copenhagen Psychosocial Questionnaire (COPSOQII, middle version, Pejtersen et al. 2010). Six psychosocial work factors were generated with scores ranging from 0 to 100: Leadership quality, social support from colleagues, work-family conflict, possibilities for development, quantitative demands, and influence at work. High scores indicate a high expression of the concept. A detailed description of the scale construction in lidA is given by Willner (2013). Following recommendations by Willner (2013), one item was deleted to generate the sum score for possibilities for development.

\section{Demographics and employment background information}

Sociodemographic and employment background information from $\mathrm{t} 1$ was considered in the analyses. This includes gender (male/female), year of birth (1959/1965), vocational education (low: no qualification, vocational operational education; off-the-job training / medium: technical school; master school / high: higher vocational education, university education), and weekly working time (full time/part time/ marginal employment). Additionally, seniority at $\mathrm{t} 1$, indicating the duration of employment with the same employer (quantified in years), was considered.

\section{Statistical analyses}

First, sociodemographic and employment variables were tested for significant differences between the groups using the $\chi^{2}$ statistic and one-way analyses of variance.

Second, the group means of mental and physical health, work ability, and the six psychosocial work factors were compared across the three waves. GLM Repeated Measures ANOVAs were performed to investigate within group and between group differences occurring between $\mathrm{t} 1$ and $\mathrm{t} 2$. Three effects were tested: The main time effect, indicating a significant change of the outcome over time, the main group effect, indicating a significant difference between the four groups in the outcome, and the interaction effect group*time, indicating significant different group changes over time. In addition to the main group effect, Post hoc tests (Bonferroni corrected) were conducted to indicate which groups differ in which way from each other. A significant main group effect supports Hypothesis 1 and a significant interaction effect group*time supports Hypothesis 2. All statistical analyses were performed using SPSS version 25.0.

\section{Results}

\section{Group descriptions}

Of the eligible 2811 participants, $13.5 \%$ changed employer between $\mathrm{t} 1$ and $\mathrm{t} 2,7.1 \%$ were EL and $6.4 \%$ were RL (Table 1). The largest proportion of participants was ES (73.3\%), 13.2\% stayed with their employer although they preferred to leave (RS). Among EL there were more women and among ES more older participants than in the other groups. Participants with low vocational education were overrepresented in RS and marginal workers in EL. Seniority at $\mathrm{t} 1$ was in both leavers' groups, EL and RL, substantially lower than in RS and ES.

\section{H1. Group differences in health, work ability, and psychosocial work factors}

Sample and group means as well as confidence intervals for mental and physical health, work ability, and the six psychosocial work factors at $\mathrm{t} 1$ and $\mathrm{t} 2$ are shown in Table 2 . 
Table 1 Sample and group characteristics

\begin{tabular}{|c|c|c|c|c|c|c|c|c|c|c|}
\hline & \multicolumn{2}{|c|}{$\begin{array}{l}\text { Sample } \\
(n=2811,100.0 \%)\end{array}$} & \multicolumn{2}{|c|}{$\begin{array}{l}\text { Enthusiastic leavers } \\
(n=199,7.1 \%)\end{array}$} & \multicolumn{2}{|c|}{$\begin{array}{l}\text { Reluctant leavers } \\
(n=179,6.4 \%)\end{array}$} & \multicolumn{2}{|c|}{$\begin{array}{l}\text { Reluctant stayers } \\
(n=370,13.2 \%)\end{array}$} & \multicolumn{2}{|c|}{$\begin{array}{l}\text { Enthusiastic stayers } \\
(n=2063,73.4 \%)\end{array}$} \\
\hline & $\%$ & $\mathrm{M}(\mathrm{SD})$ & $\%$ & $\mathrm{M}(\mathrm{SD})$ & $\%$ & $\mathrm{M}(\mathrm{SD})$ & $\%$ & $\mathrm{M}(\mathrm{SD})$ & $\%$ & $\mathrm{M}(\mathrm{SD})$ \\
\hline \multicolumn{11}{|l|}{ Gender* a } \\
\hline Male & 44.9 & & 34.7 & & 43.0 & & 43.0 & & 46.4 & \\
\hline Female & 55.1 & & 65.3 & & 57.0 & & 57.0 & & 53.6 & \\
\hline \multicolumn{11}{|l|}{ Year of birth*** } \\
\hline 1959 & 44.9 & & 35.2 & & 34.1 & & 38.4 & & 47.9 & \\
\hline 1965 & 55.1 & & 64.8 & & 65.9 & & 61.6 & & 52.1 & \\
\hline \multicolumn{11}{|l|}{ Vocational education } \\
\hline Low & 20.3 & & 19.8 & & 27.5 & & 21.3 & & 19.6 & \\
\hline Medium & 56.8 & & 58.9 & & 51.1 & & 57.9 & & 56.9 & \\
\hline High & 22.9 & & 21.3 & & 21.3 & & 20.8 & & 23.6 & \\
\hline \multicolumn{11}{|l|}{ Weekly working time**** } \\
\hline Full time & 66.7 & & 54.8 & & 66.5 & & 68.1 & & 67.6 & \\
\hline Part time & 29.0 & & 35.2 & & 26.3 & & 30.3 & & 28.5 & \\
\hline Marginal employment & 4.3 & & 10.1 & & 7.3 & & 1.6 & & 3.9 & \\
\hline Seniority*** & & $16.3(10.4)$ & & $8.8(8.0)$ & & $10.1(9.3)$ & & $15.1(9.4)$ & & $17.8(10.4)$ \\
\hline
\end{tabular}

$M$ mean, $S D$ standard deviation

${ }^{a}$ Chi-square or one-way ANOVA significant group difference, ${ }^{*} p<.05$, ${ }^{* * *} p<.001$

The results of the Repeated Measures ANOVA support H1 (main group effect, Table 3): The groups differ significantly in terms of health, work ability, and psychosocial work factors. Notably, the main group effect of leadership quality shows a high effect size $\left(\eta^{2}=0.08\right)$ in contrast to the other outcomes. The Post hoc tests indicate that in all cases the group of RS significantly differ from one or more other groups. This group exhibited the most adverse mean scores for work ability, the health indicators, and all psychosocial work factors.

\section{H2. Group changes over time}

The Repeated Measures ANOVAs support H2 for most outcomes (interaction effect group*time, Table 3): The groups differ significantly with respect to changes over time in terms of mental, but not physical health, in terms of work ability and the psychosocial work factors, leadership quality, work-family conflict, possibilities for development, and quantitative demands. Again, the greatest effect size was found for the interaction effect for leadership quality $\left(\eta^{2}=0.03\right)$.

Table 2 provides insight of these changes: In the group of EL, the ratings for the new job at $\mathrm{t} 2$ indicate substantial improvements for mental health, work ability, and leadership quality, work-family conflict, possibilities for development, and quantitative demands in relation to the previous job (t1). RL reported, on one hand, improvements in work ability, leadership quality, and support from colleagues, and on the other hand, deteriorations in influence at work. RS reported deteriorations in leadership quality, possibilities for development, influence at work, and work-family conflict. Among ES the mean scores for the outcomes changed only slightly over time.

\section{Discussion}

In our analyses we find that the four employer change groups depicted by Hom et al. (2012) already differ at t1 in terms of health, work ability, and psychosocial work factors and that these outcomes change in different characteristic patterns over time. There were only marginal changes of outcomes in the group of ES. Most outcomes improved substantially over time among EL, some also among RL. RS already reported poor outcomes in 2014 and exhibited a further deterioration while staying at the undesired workplace.

In relation to economically liberal countries, the frequency of employer changes tends to be low in the German labor market (Buchholz 2008). However, in our study, the proportion of EL $(7.1 \%)$ and RL (6.4\%) over four years is notably high, considering that older employees, in particular, were found to have substantial obstacles to employer change and change rarely (Bailey and Hansson 1995; Carless and Arnup 2011). The high proportion of RS found in the study 


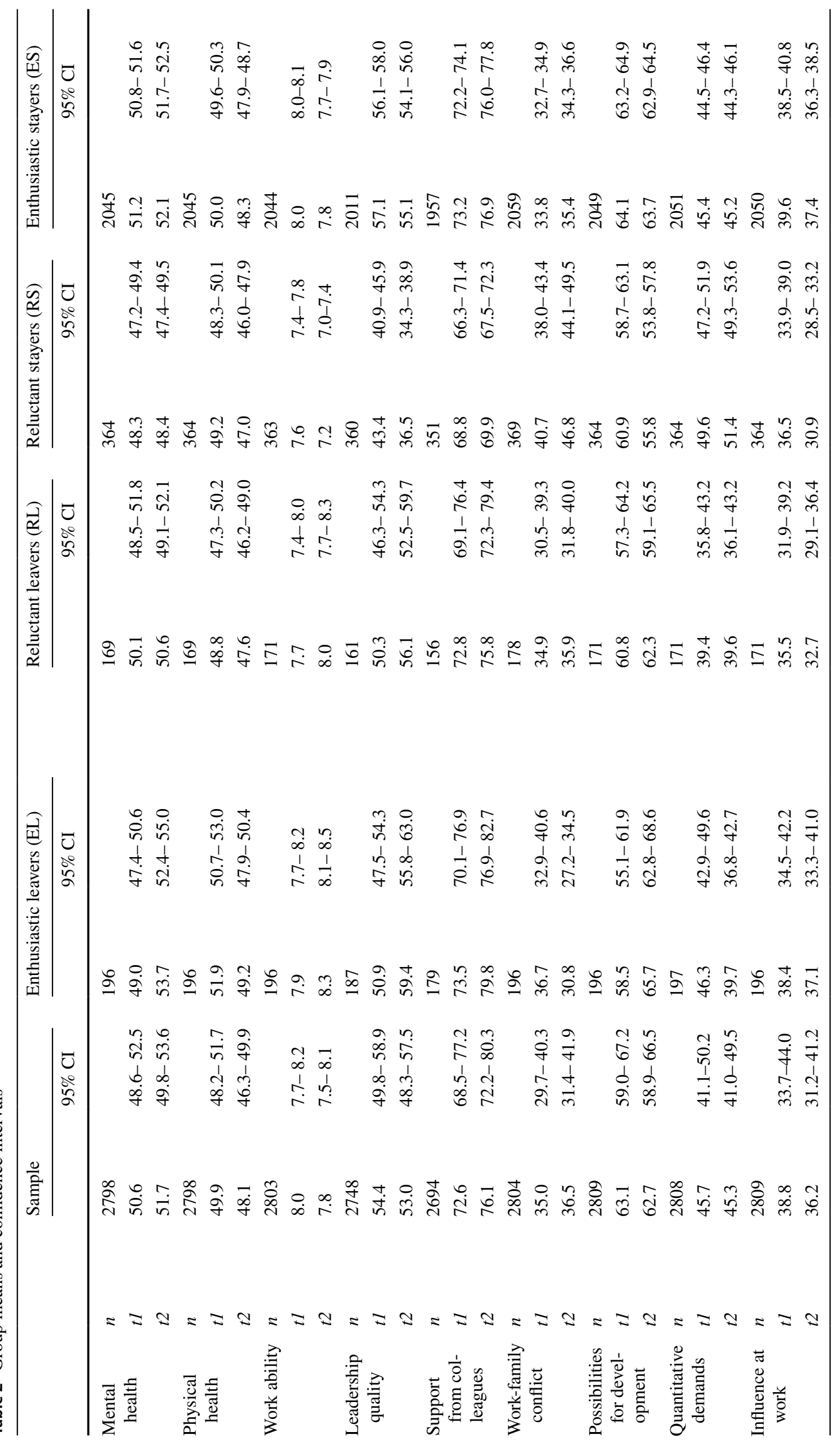


Table 3 Repeated Measures ANOVA

\begin{tabular}{|c|c|c|c|}
\hline & & $\begin{array}{l}\text { Hypothesis sup- } \\
\text { ported }\end{array}$ & $\begin{array}{l}\text { Significant post-hoc comparison at } \\
p>.05 \text { (Bonferroni-corrected) }\end{array}$ \\
\hline \multicolumn{4}{|l|}{ Mental health } \\
\hline Main time effect & $\mathrm{F}(1,2787)=27.19, p<.001$, partial $\eta^{2}=.01$ & - & - \\
\hline Main group effect & $\mathrm{F}(3,2787)=16.36, p<.001$, partial $\eta^{2}=.02$ & Yes & $\mathrm{ES}>\mathrm{RS}, \mathrm{EL}>\mathrm{RS}$ \\
\hline Interaction effect group*time & $\mathrm{F}(3,2787)=9.54, p<.001$, partial $\eta^{2}=.01$ & Yes & - \\
\hline \multicolumn{4}{|l|}{ Physical health } \\
\hline Main time effect & $\mathrm{F}(1,2787)=59.11, p<.001$, partial $\eta^{2}=.02$ & - & - \\
\hline Main group effect & $\mathrm{F}(3,2787)=4.98, p<.01$, partial $\eta^{2}=.01$ & Yes & $\mathrm{EL}>\mathrm{RS}, \mathrm{EL}>\mathrm{RL}$ \\
\hline Interaction effect group*time & $\mathrm{F}(3,2787)=1.42, p=.236$, partial $\eta^{2}=.00$ & No & - \\
\hline \multicolumn{4}{|l|}{ Work ability } \\
\hline Main time effect & $\mathrm{F}(1,2793)=1.75, p=.186$, partial $\eta^{2}=.00$ & - & - \\
\hline Main group effect & $\mathrm{F}(3,2793)=20.09, p<.001$, partial $\eta^{2}=.02$ & Yes & $\mathrm{ES}>\mathrm{RS}, \mathrm{EL}>\mathrm{RS}, \mathrm{RL}>\mathrm{RS}$ \\
\hline Interaction effect group*time & $\mathrm{F}(3,2793)=12.22, p<.001$, partial $\eta^{2}=.01$ & Yes & - \\
\hline \multicolumn{4}{|l|}{ Leadership quality } \\
\hline Main time effect & $\mathrm{F}(1,2698)=4.57, p<.05$, partial $\eta^{2}=.00$ & - & - \\
\hline Main group effect & $\mathrm{F}(3,2698)=73.73, p<.001$, partial $\eta^{2}=.08$ & Yes & $\mathrm{ES}>\mathrm{RS}, \mathrm{EL}>\mathrm{RS}, \mathrm{RL}>\mathrm{RS}$ \\
\hline Interaction effect group*time & $\mathrm{F}(3,2698)=23.42, p<.001$, partial $\eta^{2}=.03$ & Yes & - \\
\hline \multicolumn{4}{|l|}{ Support from colleagues } \\
\hline Main time effect & $\mathrm{F}(1,2628)=19.65, p<.001$, partial $\eta^{2}=.01$ & - & - \\
\hline Main group effect & $\mathrm{F}(3,2628)=10.32, p<.001$, partial $\eta^{2}=.01$ & Yes & $\mathrm{ES}>\mathrm{RS}, \mathrm{EL}>\mathrm{RS}, \mathrm{RL}>\mathrm{RS}$ \\
\hline Interaction effect group*time & $\mathrm{F}(3,2628)=1.87, p=.133$, partial $\eta^{2}=.00$ & No & - \\
\hline \multicolumn{4}{|l|}{ Work-family conflict } \\
\hline Main time effect & $\mathrm{F}(1,2795)=0.79, p=.374$, partial $\eta^{2}=.00$ & - & - \\
\hline Main group effect & $\mathrm{F}(3,2795)=17.26, p<.001$, partial $\eta^{2}=.02$ & Yes & $\mathrm{ES}<\mathrm{RS}, \mathrm{EL}<\mathrm{RS}, \mathrm{RL}<\mathrm{RS}$ \\
\hline Interaction effect group*time & $\mathrm{F}(3,2795)=8.49, p<.001$, partial $\eta^{2}=.01$ & Yes & - \\
\hline \multicolumn{4}{|l|}{ Possibilities for development } \\
\hline Main time effect & $\mathrm{F}(1,2805)=2.20, p=.138$, partial $\eta^{2}=.00$ & - & - \\
\hline Main group effect & $\mathrm{F}(3,2805)=10.97, p<.001$, partial $\eta^{2}=.01$ & Yes & $\mathrm{ES}>\mathrm{RS}$ \\
\hline Interaction effect group*time & $\mathrm{F}(3,2805)=18.95, p<.001$, partial $\eta^{2}=.02$ & Yes & - \\
\hline \multicolumn{4}{|l|}{ Quantitative demands } \\
\hline Main time effect & $\mathrm{F}(1,2804)=3.68, p=.055$, partial $\eta^{2}=.00$ & - & - \\
\hline Main group effect & $\mathrm{F}(3,2804)=14.68, p<.001$, partial $\eta^{2}=.02$ & Yes & $\mathrm{ES}<\mathrm{RS}, \mathrm{ES}>\mathrm{RL}, \mathrm{EL}<\mathrm{RS}, \mathrm{RL}<\mathrm{RS}$ \\
\hline Interaction effect group*time & $\mathrm{F}(3,2804)=7.24, p<.001$, partial $\eta^{2}=.01$ & Yes & - \\
\hline \multicolumn{4}{|l|}{ Influence at work } \\
\hline Main time effect & $\mathrm{F}(1,2803)=17.32, p<.001$, partial $\eta^{2}=.01$ & - & - \\
\hline Main group effect & $\mathrm{F}(3,2803)=6.09, p<.001$, partial $\eta^{2}=.01$ & Yes & $\mathrm{ES}>\mathrm{RS}$ \\
\hline Interaction effect group*time & $\mathrm{F}(3,2803)=2.25, p=.081$, partial $\eta^{2}=.00$ & No & - \\
\hline
\end{tabular}

$E L$ enthusiastic leavers, $R L$ reluctant leavers, $E S$ enthusiastic stayers, $R S$ reluctant stayers

(13.2\%), however, may be interpreted as the effect of the obstacles mentioned above.

\section{Enthusiastic leavers}

As theorized by Hom et al. (2012), the psychosocial work factors improved substantially with a voluntary change of employer. At t1, several factors clearly showed more adverse mean scores among the EL than for RS or ES, namely leadership quality, possibilities for development, and work-family conflict, all established causes for voluntary change (Raeve et al. 2008; Rubenstein et al. 2018; Nouri and Parker 2013). Also work ability and mental health improved strongly after the change, but not physical health, indicating the relevance of differentiation of health when investigating work and health. These results are in line with those from Liljegren and Ekberg (2008) who found job mobility to be a predictor of mental, but not physical health, though mental health not as a predictor of job mobility. 
Another observation makes the group of EL outstanding: At $\mathrm{t} 2$ the EL reported the best mental health, work ability and leadership quality, and the lowest work-family conflict of all four groups depicted by Hom et al. (2012).

\section{Reluctant leavers}

According to our findings, the group of RL is, before the change, characterized by low leadership quality, low influence at work, and very low quantitative demands. However, the involuntary change seems to go along with considerable improvements, such as work ability, leadership quality, and support from colleagues, but also deteriorations for influence at work. Our analyses can neither confirm nor reject the assumptions that RL were low performers as described in Jackofsky's model on turnover and job performance from 1984.

There were no changes in the two health outcomes over time, showing the importance of a conceptual distinction of health and work ability. Even if the workers' health does not change, work ability can be improved by adapting the work situation (Ebener and Hasselhorn 2016).

\section{Reluctant stayers}

Already at t1, the group of RS stands out with respect to several work exposures and outcomes and stands particularly in contrast to the EL. In terms of leadership quality, work-family conflict, possibilities for development, quantitative demands, and influence at work, this group already exhibited poor or even worst mean scores in the sample which then further deteriorated over the next four years. These results may reflect lack of person-work fit in this group as concluded by Hom et al. (2012) and also assumptions based on the job lock and stuck at work theories (Huysse-Gaytandjieva et al. 2013): Specifically those with poor work find it difficult to change to a better job due to a lack of opportunities and low qualifications.

Also work ability declined in this group which is in line with conclusions from the international JPI UEP working group, that work ability declines with age, especially in jobs with physically strenuous tasks and that some older workers may be "locked" in such jobs (Hasselhorn and Apt 2015). In terms of health, our results indicate stable mental health over time, at a very low level, however, and a deterioration of physical health, which is of comparable size as in the other groups. A Swedish working group found that being locked-in is detrimental to well-being (Stengård et al. 2016).

\section{Enthusiastic stayers}

As described by Hom et al. (2012) the group of ES differs clearly from all others: While there are many significant and different changes over time among EL, RL, and RS, only very small changes were found in this largest group, the ES. Although it is a large group, deteriorations in physical health and work ability were found, which may be attributed to aging (Kooij 2015). Notable is that the ES had the highest seniority at $\mathrm{t} 1$ (Table 1), which may be indicative of a longlasting person-work fit for many (Hom et al. 2012).

\section{Strengths and limitations}

The strength of the lidA study is that the four occupational change groups suggested by Hom et al. (2012) can be identified and examined in depth, over time and among older workers, because of the large age-homogeneous sample size and the longitudinal study design. Another advantage is the representativeness of the sample for the older German socially insured working population of similar age. Limitations are that the study focuses on psychosocial work factors only, did not include employees, who became unemployed, and that the different group sizes may impede comparability between the groups of EL, RL, and RS and the greatest group of ES.

\section{Conclusions}

Concluding, we confirm theoretical suggestions that a change of employer may lead to considerable improvements among a range of psychosocial work factors for older workers, especially when the step is taken voluntarily, but also following reluctant leaving. Our research results imply that older workers generally take the initiative to change their employer because they want to improve adverse psychosocial working conditions. Yet, voluntary changes have the potential to improve mental health and work ability as well.

If both changing groups-those changing voluntarily and involuntarily-benefit from an employer change, we may conclude that an inclusive labor market policy for older workers allowing for high job mobility may have the potential to contribute to considerable improvements of workers' individual working conditions, health, and work ability, thereby increasing work participation of older workers and extending working lives.

Further, our results indicate that the group of reluctant stayers requires special attention from employers and policy and might also benefit from an inclusive labor market policy. This group of workers rates its own work situation increasingly poorer while staying at the undesired workplace. It may pose a risk group with regard to work ability, work motivation, and therefore employment participation at higher working age. 
Considering the overall relevance of this topic and the growing availability of good data, research should dedicate more resources to this field. Thereby, research should differentiate voluntary and involuntary changes and not overlook the great risk group of reluctant stayers. Conceptually, physical and mental health should be differentiated from work ability. Finally, besides investigating the determinants, future studies should look into the short- and long-term consequences of actual and desired employer changes among older workers and their relation to working life duration and quality.

Author contributions NG and HMH designed the study, NG performed the analyses, NG has written the first draft of the article, and HMH and NG critically reviewed and revised the manuscript and approved the final article.

Funding This work was supported by the Ministry of Culture and Science of the German State of North Rhine-Westphalia; and the German Social Accident Insurance, DGUV [FP 403]. Open Access funding provided by Projekt DEAL.

\section{Compliance with ethical standards}

Conflict of interest The authors declare that they have no conflict of interest.

Ethical approval The lidA Study has received ethical approval from the Ethics Commission of the University of Wuppertal dated from 05.12.2008 and 20.11.2017 [MS/BB 171025 Hasselhorn].

Open Access This article is licensed under a Creative Commons Attribution 4.0 International License, which permits use, sharing, adaptation, distribution and reproduction in any medium or format, as long as you give appropriate credit to the original author(s) and the source, provide a link to the Creative Commons licence, and indicate if changes were made. The images or other third party material in this article are included in the article's Creative Commons licence, unless indicated otherwise in a credit line to the material. If material is not included in the article's Creative Commons licence and your intended use is not permitted by statutory regulation or exceeds the permitted use, you will need to obtain permission directly from the copyright holder. To view a copy of this licence, visit http://creativecommons.org/licenses/by/4.0/.

\section{References}

Alcover C-M, Topa G (2018) Work characteristics, motivational orientations, psychological work ability and job mobility intentions of older workers. PLoS ONE 13(4)

Bäcker G, Jansen A, Schmitz J (2017) Rente erst ab 70? Probleme und Perspektiven des Altersübergangs [Pension only from the age of 70 ? Problems and perspectives of the age transition]

Bailey LL, Hansson RO (1995) Psychological obstacles to job or career change in late life. J Gerontol B Psychol Sci Soc Sci 50B(6):280288. https://doi.org/10.1093/geronb/50B.6.P280

Behrens J (1998) Länger erwerbstätig durch Arbeits- und Laufbahngestaltung. Personal- und Organisationsentwicklung zwischen begrenzter Tätigkeitsdauer und langfristiger Erwerbstätigkeit
[Longer employed through work and career design. Personnel and organizational development between limited duration of employment and long-term employment]. In: Behrens J, Morschhäuser M, Viebrok H, Zimmermann E (eds) Länger erwerbstätig — aber wie? [Working longer - but how?]. VS Verlag für Sozialwissenschaften, Wiesbaden, pp 71-115

Brauer K, Clemens W (eds) (2010) Zu alt? "Ageism" und Altersdiskriminierung auf Arbeitsmärkten [Too old? Ageism and age discrimination in labor markets], 1st edn. Alter(n) und Gesellschaft, vol 20. VS Verl. für Sozialwiss, Wiesbaden

Buchholz S (2008) Die Flexibilisierung des Erwerbsverlaufs. Eine Analyse von Einstiegs- und Ausstiegsprozessen in Ost- und Westdeutschland [The flexibilisation of the employment history. An analysis of entry and exit processes in East and West Germany]. VS Verlag für Sozialwissenschaften / GWV Fachverlage GmbH Wiesbaden, Wiesbaden

Carless SA, Arnup JL (2011) A longitudinal study of the determinants and outcomes of career change. J Vocat Behav 78(1):80-91. https ://doi.org/10.1016/j.jvb.2010.09.002

Chadi A, Hetschko C (2014) The magic of the new: How job changes affect job satisfaction. IAAEU Discuss Paper Series Economs. https://doi.org/10.1111/jems.12217

Ebener M, Hasselhorn HM (2016) Arbeitsfähigkeit in Organisationen messen und erhalten - ein Konzept und ein Instrument aus der Arbeitsmedizin [Measuring and maintaining work ability in organizations - a concept and instrument from occupational medicine]. Wirtschaftspsychologie 18(3):48-58

Ebener M, Hasselhorn HM (2019) Validation of Short Measures of Work Ability for Research and Employee Surveys. Int J Environ Res Public Health. https://doi.org/10.3390/ijerph16183386

Hasselhorn HM, Apt W (2015) Understanding employment participation of older workers: Creating a knowledge base for future labour market challenges. Springer, Berlin

Hasselhorn HM, Peter R, Rauch A, Schröder H, Swart E, Bender S, Du Prel J-B, Ebener M, March S, Trappmann M, Steinwede J, Müller BH (2014) Cohort profile: The lidA cohort study-a German cohort study on work, age, health and work participation. Int J Epidemiol 43(6):1736-1749. https://doi.org/10.1093/ije/ dyu021

Hom PW, Mitchell TR, Lee TW, Griffeth RW (2012) Reviewing employee turnover: Focusing on proximal withdrawal states and an expanded criterion. Psychol Bull 138(5):831-858. https://doi. org/10.1037/a0027983

Hulin CL, Roznowski M, Hachiya D (1985) Alternative opportunities and withdrawal decisions: Empirical and theoretical discrepancies and an integration. Psychol Bull 97(2):233-250. https://doi. org/10.1037/0033-2909.97.2.233

Huysse-Gaytandjieva A, Groot W, Pavlova M (2013) A new perspective on job lock. Soc Indic Res 112(3):587-610. https://doi. org/10.1007/s11205-012-0072-2

Jackofsky EF (1984) Turnover and Job Performance: An Integrated Process Model. Acad Manag Rev 9(1):74. https://doi. org/10.2307/258234

Jahn F, Ulbricht S (2011) Mein nächster Beruf" - Personalentwicklung für Berufe mit begrenzter Tätigkeitsdauer: Teil 1: Modellprojekt in der stationären Krankenpflege ['My next job' - Personnel development for jobs with a limited duration of employment. Part 1: Model project in inpatient nursing]. iga. Report 17, Berlin

Kooij DTAM (2015) Successful aging at work: The active role of employees. WORKAR 1(4):309-319. https://doi.org/10.1093/ workar/wav018

Lee TW, Mitchell TR, Holtom BC, McDaniel LS, Hill JW (1999) The unfolding model of voluntary turnover: A replication and extension. Acad Manag 42(4):450-462 
Liljegren M, Ekberg K (2008) The longitudinal relationship between job mobility, perceived organizational justice, and health. BMC Public Health 8:164. https://doi.org/10.1186/1471-2458-8-164

Mobley WH (1977) Intermediate linkages in the relationship between job satisfaction and employee turnover. J Appl Soc Psychol 62(2):237-240

Mobley WH, Griffeth RW, Hand HH, Meglino BM (1979) Review and conceptual analysis of the employee turnover process. Psychol Bull 86(3):493-522. https://doi.org/10.1037/0033-2909.86.3.493

Morschhäuser M (ed) (2002) Gesund bis zur Rente. Konzepte gesundheits- und alternsgerechter Arbeits- und Personalpolitik [Healthy until retirement. Concepts of health and age-appropriate work and personnel policy]. Broschürenreihe. Fraunhofer-IRB-Verl, Stuttgart

Morschhäuser M (2006) Reife Leistung: Personal- und Qualifizierungspolitik für die künftige Altersstruktur [Good job. Personnel and qualification policy for the future age structure], 1st edn. Nomos Verlagsgesellschaft mbH \& Co. KG, Baden-Baden

Mowday RT, Porter LW, Steers RM (1982) Employee-organization linkages: The psychology of commitment, absenteeism, and turnover. Academic Press, New York, Organizational and occupational psychology

Nouri H, Parker RJ (2013) Career growth opportunities and employee turnover intentions in public accounting firms. The British Accounting Review 45(2):138-148. https://doi.org/10.1016/j. bar.2013.03.002

Nübling M, Andersen HH, Mühlbacher A (2006) Data Documentation 16. Entwicklung eines Verfahrens zur Berechnung der körperlichen und psychischen Summenskalen auf Basis der SOEP - Version des SF 12 (Algorithmus) des SF 12 (Algorithmus) [Data Documentation 16. Development of a method for the calculation of the physical and psychological sum scales on the basis of the SOEP version of the SF 12 (algorithm) of the SF 12 (algorithm)], Berlin

Pejtersen JH, Kristensen TS, Borg V, Bjorner JB (2010) The second version of the Copenhagen Psychosocial Questionnaire. Scand J Public Health 38(3 Suppl):8-24. https://doi.org/10.1177/14034 94809349858

Raeve Ld, Jansen NWH, van den Brandt PA, Vasse R, Kant IJ (2008) Interpersonal conflicts at work as a predictor of self-reported health outcomes and occupational mobility. Occup Environ Med 66(1):16-22. https://doi.org/10.1136/oem.2007.037655

Rauch A, Burghardt A, Eggs J, Tisch A, Tophoven S (2015) lidA-leben in der Arbeit. German cohort study on work, age and health. J
Labour Market Res 48(3):195-202. https://doi.org/10.1007/s1265 1-015-0189-2

Reineholm C, Gustavsson M, Liljegren M, Ekberg K (2012) The importance of work conditions and health for voluntary job mobility: A two-year follow-up. BMC Public Health 12:682. https://doi. org/10.1186/1471-2458-12-682

Rubenstein AL, Eberly MB, Lee TW, Mitchell TR (2018) Surveying the forest: A meta-analysis, moderator investigation, and futureoriented discussion of the antecedents of voluntary employee turnover. Pers Psychol 71(1):23-65. https://doi.org/10.1111/ peps. 12226

Schneider L (2010) Seniorität und Beschäftigungsmobilität - Warum Ältere seltener Job und Beruf wechseln [Seniority and Employment Mobility - Why older people rarely switch jobs and occupation]. In: Salzmann T, Skirbekk V, Weiberg M (eds) Wirtschaftspolitische Herausforderungen des demografischen Wandels. VS Verlag für Sozialwissenschaften, Wiesbaden, pp 107-129

Stengård J, Bernhard-Oettel C, Berntson E, Leineweber C, Aronsson G (2016) Stuck in a job: Being "locked-in" or at risk of becoming locked-in at the workplace and well-being over time. Work Stress 30(2):152-172. https://doi.org/10.1080/02678373.2016.1163804

Trevor CO (2001) Interactions among actual ease-of-movement determinations and job satisfaction in the prediction of voluntary turnover. Acad Manag 44(4):621-638

Wagenaar AF, Kompier MAJ, Houtman ILD, van den Bossche SNJ, Taris TW (2012) Impact of employment contract changes on workers' quality of working life, job insecurity, health and workrelated attitudes. J Occup Health 54(6):441-451

Ware JE, Kosinski M, Keller SD (1995) SF-12: How to score the SF-12 physical and mental health summary scales, 2nd edn. Health Institute, New England Medical Center, Boston

Ware JE, Kosinski M, Keller SD (1996) A 12-Item Short-Form Health Survey: Construction of scales and preliminary tests of reliability and validity. Med Care 34(3):220-233

Willner M (2013) Psychometrische Analysen von Skalen zur Erfassung psychosozialer Aspekte der Arbeitstätigkeit und Arbeitsumgebung.: Dissertation zur Erlangung des akademischen Grades eines Doktors der Sicherheitswissenschaften. Dissertation, Universität Wuppertal

Publisher's Note Springer Nature remains neutral with regard to jurisdictional claims in published maps and institutional affiliations. 